\title{
Capital Structure andCorporate Governance practices. Evidence from Listed Non-Financial Firms on Nairobi Securities Exchange Kenya.
}

\author{
${ }^{1}$ Mwalati Solomon Chitiavi, ${ }^{2}$ Maniagi Gerald Musiega ${ }^{3}$ Dr. Ondiek B. Alala \\ ${ }^{4}$ Dr. Musiega Douglas ${ }^{5}$ Maokomba O. Christopher \\ ${ }^{1,2}$ School of Human Resource and Development, Jomo Kenyatta University of Agriculture and \\ Technology, Kakamega campus, \\ ${ }^{3}$ Lecturer Accounting and Finance, School of Business and economics, university of Kabianga. Kericho Kenya \\ ${ }^{4}$ Director ,Jomo Kenyatta University of Agriculture and Technology, Kakamega campus. Kenya \\ ${ }_{5}^{5}$ Lecturer of economics, School of Human Resource and Development, Jomo Kenyatta University of Agriculture \\ and Technology,Kakamega campus, Kenya
}

\begin{abstract}
This paper examines the impact of corporate governance on capital structure for firms listed on NSE Kenya. The total population of non-financial firms is 50.A sample of 30 companies whose data for 5 years from 2007-2011 was selected. The study uses five corporate governance proxies: Board size (BS), Ownership concentration (ONC), Institutional share ratio (ISR), CEO duality (CED), Board independence (BI) as independent variables. Four capital structures variables are: Long term debt to asset ratio (LTDA), Short term debt to asset ratio (STDA), Debt equity ratio (DE), and Total debt to asset ratio (TD) as dependent variables. The analysis used both descriptive and inferential analysis where correlation and linear regression were used.An average of 7 directors are on the board of firms with 93\% of firms CEO doubling as a director.Using model 1 regression equation positive correlation is shown between TD with corporate governance proxies CED which is significant at 95\% significant level. Using model 2 regression equation size of the firmSz taken as natural logarithm of sales as a moderating variable CED is negatively correlated to STD and DE and is significant implying firms tend to adopt pecking order theory to avoid more debt
\end{abstract}

Key words: capital structure,corporate governance, Durbin Watson,Nairobi Security Exchange,.

\section{Introduction}

Corporate governance is defined as the process and structure used to direct and manage business affairs of the company towards enhancing prosperity and corporate accounting with the ultimate objective of realizing shareholders long-term value while taking into account the interest of other stakeholders. (The Capital Markets Act Cap. 485a Gazette Notice No. 33622002)

Good corporate governance practices for listed firms must be nurtured and encouraged to evolve as a matter of best practice.Minimum standards of good governance are required. The directors of every public listed require adoptinggood corporate governance practices as part of their continuing listing obligations. Compliance withgood corporate governance practices is essential part of disclosure obligations in the corporate annual reports

In Kenya it is a requirement for public listed company to disclose on an annual basis, its annual report, a statement of the directors as to whether the company is complying with corporate governanceguidelines with effect from the financial year ending 2002, as prescribed under the Capital Markets (Securities) (Public Offers, Listing and Disclosures) Regulations, 2002.

The Board of directors of a firm has to fulfill its fiduciary obligations to the shareholders by maintaining control over the strategic, financial, operational and compliance issues. The Board has to provide direction and guidance on strategic and general policy matters, formost firms this responsibility is delegated to the Managing Director to conduct the day-to-day business. The Board may consist of non- executive and independent directors (including the Chairman).

In Kenya, dealing in shares and stocks started in the 1920's when she was still a British colony. In 1951, an Estate Agent Francis Drummond established the first professional stock broking firm. In 1954 the Nairobi Stock Exchange was then constituted as a voluntary association of stockbrokers registered under the Societies Act. Africans and Asians were not permitted to trade in securities, until after the attainment of independence in 1963, the business of dealing in shares was confined only to the resident European community. At independence, stock market activity came to a standstill due to uncertainty about the future of independent Kenya. 
1988 saw the first privatization through the NSE of the successful sale of a $20 \%$ government stake in Kenya Commercial Bank. The sale left the Government of Kenya and affiliated institutions retaining 80\% ownership of the bank.

In 1994 the NSE 20-Share Index recorded an all-record high of 5030 points. The NSE was rated by the International Finance Corporation (IFC) as the best performing market in the world with a return of $179 \%$ in dollar terms. The same year NSE also moved to Nation Centre setting up a computerized delivery and settlement system (DASS) and the number of stockbrokers increased with the licensing of 8 new brokers. (NSE Website)

In July 2011, the Nairobi Stock Exchange Limited changed its name to the Nairobi Securities Exchange Limited. The change of name reflected the strategic plan of the Nairobi Securities Exchange to evolve into a full service securities exchange which supports trading, clearing and settlement of equities, debt, derivatives and other associated instruments.

Capital structure can be defined as a mix of debt and equity which firms use to finance their activities. Firms used various proportion mix of debt and equity in order to maximize the value of a firm. (Abor2007)

\section{Statement of a the problem}

Corporate governance has become a global issue due to financial crisis that has taken centre stage in the globe. Most empirical research has focused on the impact of corporate on performance. A few researches for firms on developed and developing market has explored this area,(Abor2007). No such study has been conducted to investigate between corporate governance and capital structure for firms listed on the NSE.

\section{Research objectives}

i. To determine the effect of long term debt/ asset ratio on corporate governance of non- financial firms on NSE.

ii. To determine the relationship if any between short term debt/ asset ratio and corporate governance proxies of non- financial firms on NSE

iii. To determine the effect of total debt/ asset ratio on corporate governance of non-financial firms on NSE

\section{Research questions}

i. Does long term debt/ Asset ratio has an effect on corporate governance of non-financial firms listed on Nairobi Securities Exchange?

ii. Is there any relationship between short term debt/ asset ratio and corporate governance of non-financial firms listed on Nairobi Securities Exchange?

iii. Do total debt/ Asset ratio have an effect on corporate governance of non-financial firms on Nairobi Securities Exchange?

\section{V. literature review}

Abor, (2007) examined Capital structure, corporate governance, Debts, Financing on listed firms in Ghana. The empirical results showed statistically significant and positive associations between capital structure and board size, board composition, and CEO duality. The results generally indicate that Ghanaian listed firms pursue high debt policy with larger board size, higher percentage of non-executive directors, and CEO duality. The results also show a negative (though statistically insignificant) relationship between the tenure of the CEO and capital structure, suggesting that, entrenched CEOs employ lower debt in order to reduce the performance pressures associated with high debt capital

Akram B. \& Ahmad A.(2010) researched on the effect of corporate governance and ownership structure on capital structure of Iranian listed companies the results showed that there is a positive relationship between leverage and the size of firm. This appears rational as larger firms have more assets for collateral and it is easier for them to negotiate better terms with lenders. Institutional shareholding was positively correlated with capital structure. This could be due to efficient monitoring and reduction of the agency cost and managerial opportunism. The size of board was found negatively correlated with debt to equity ratio indicating larger boards may exert pressure on managers to follow lower gearing levels and enhance firm performance. An aspect of this observation was that larger companies have larger boards and larger companies with larger assets base are more inclined to incur debt at favorable terms.

Noriza M (2010) researched on the corporate governance compliance and effects to capital structure in Malaysia. The regression results showed that debt equity was negatively correlated to CEO duality $(-2.069)$ and positively correlated to board size (2.556) both significant at $95 \%$ confidence level .this could be due to the facts that majority of the companies has 6 to 10 directors. 
Rehman, M. A., Rehman, R. U. andRaoof, A. (2010) investigated the relationship between corporate governance and capital structure of randomly selected 19 banks of Pakistan from 2005-2006. They found a positive relationship between board size and capital structure

Saad (2010) researched oncorporate governance compliance and the effects to capital structure in Malaysia a sample of 126 Malaysian publically listed companies from four industries consumer products, industrial products, trading/services, and plantations for the period from 1998 to 2006. The results showed a negative relationship between CEO duality and capital structure, and positive relationships between board size and capital structure

Rajendran K (2012) researched on the impact of corporate governance on capital structure of Srilankan manufacturing firms, and examined the corporate governance mechanism driving firm's choice of capital structure. This study showed a positive relationship between leverage and board size, boardmeeting, proportion of non-executive directors and leadership style. This indicate that more boardcommittees could make manufacturing companies to be more prone to gearing by taking chances on externalsource of capital for modernization, expansion and aggressive exploitation of investment opportunities

Amarjit G. et al (2012) examined the perceived relationships between corporate governance and capital structure (CS) of small business service firms in India. Findings of this study showed that CS of small business service firms is positively associated with CEO dualityand Board Size.

Yinusa O.\&Babalola Y.(2012) examined the impact of corporate governance on capital structure decision of Nigerian firmsnone of thecorporate governance variables significantly affected the capital structure of the companies, the board size, profitability of the company and firm size were negatively related while the board composition, institutional holdings and management holdings were positively related to the leverage position (capital Structure) of Nigerian companies.

\section{Justification}

This study will contribute to the literature on the factors that improve the debt management and its association with corporate governance. The findings may be useful for financial managers, investors, financial management consultants, and other stakeholders in order to ensure sanity in the management of firms.

\section{Conceptual frame work}

\begin{tabular}{|c|c|}
\hline $\begin{array}{l}\text { Corporate governance } \\
\begin{array}{ll}\text { - } & \text { Board size. } \\
\text { - } & \text { Ownership concentration. } \\
\text { - } & \text { Institutional share ratio } \\
\text { - } & \text { CEO duality } \\
\text { - } & \text { Board independence }\end{array}\end{array}$ & $\begin{array}{l}\text { Capital structure } \\
\begin{array}{l}\text { - } \\
\text { - } \text { Song term debt to asset ratio } \\
\text { - Debt equity ratio } \\
\text { - Total debt }\end{array}\end{array}$ \\
\hline
\end{tabular}

VIII. Research methodology.

The study was data-based research, it will utilized secondary data from companies listed on Nairobi Securities Exchange website and companies' website. Audited financial statements, cash flow statement, and statement of change in equity for the companies selected was used; thus increasing the reliability and validity of the findings and conclusion. This database research can be replicated.

\section{Sample size and selection criteria}

The population of NSE listed non-financial firms stand at 50 companies. Simple random sampling method was used.Other criteria that the researcher used were companies that were not listed in the NSE for the duration of the five year were left out of the sample also those that did not have complete accounts were left out. The study was limited to all listed non-financial firms and those that were selected had to have complete data. The sample for the study consisted of 30 companies listed on Nairobi Securities Exchange NSE for the period of five years from 2007-2011 which is about 60\%. The sample included companies from the following nine sectorsAgricultural Sector, Automobiles and Accessories, Commercial and Services, Construction and Allied Sector, Energy and Petroleum, Insurance, Investment, Manufacturing and Allied Telecommunication and Technology. 


\section{Insert Table 1 Percentage of Sample Selected.}

\section{Data collection}

Data for this research was selected from NSE website where financial statements of all listed companies have been consolidated into a hand book, also additional information was obtained fromcompanies' websites.

\section{Variables} table below

Various variables have been used to proxies for corporate governance and capital structure, as in the

\section{Insert Table 2 variables}

\section{Data analysis}

In this research, the researcher applied both descriptive analysis and inferential analysis. Under descriptive the mean, mode, median, kurtosis and skewness were used to analyze the data. Data correlation technique was used and regression equation was used to run dependent variables capital structure proxies against independent variables corporate governance proxies. The regressions equations below were used.

\section{Regression equation}

$\mathbf{Y}_{\mathrm{LTDA}=\mathbf{a}}+\boldsymbol{\beta}_{1 \mathrm{BS}}+\boldsymbol{\beta}_{2 \mathrm{OC}}+\boldsymbol{\beta}_{31 \mathrm{O}}+\boldsymbol{\beta}_{4 \mathrm{CE}}+\boldsymbol{\beta}_{5 \mathrm{BI}}+\mathrm{e}$

$\mathbf{Y}_{\mathrm{STDA}=} \mathbf{a}+\boldsymbol{\beta}_{1 \mathrm{BS}}+\boldsymbol{\beta}_{2 \mathrm{OC}}+\boldsymbol{\beta}_{3 \mathrm{IO}}+\boldsymbol{\beta}_{4 \mathrm{CE}}+\boldsymbol{\beta}_{5 \mathrm{BI}}+\mathrm{e}$

$\mathbf{Y}_{\mathrm{DE}}=\mathbf{a}+\boldsymbol{\beta}_{1 \mathrm{BS}}+\boldsymbol{\beta}_{2 \mathrm{OC}}+\boldsymbol{\beta}_{31 \mathrm{O}}+\boldsymbol{\beta}_{4 \mathrm{CE}}+\boldsymbol{\beta}_{5 \mathrm{BI}}+\mathbf{e}$

$\mathbf{Y}_{\mathrm{TD}=} \mathbf{a}+\boldsymbol{\beta}_{1 \mathrm{BS}}+\boldsymbol{\beta}_{2 \mathrm{OC}}+\boldsymbol{\beta}_{3 \mathrm{IO}}+\boldsymbol{\beta}_{4 \mathrm{CE}}+\boldsymbol{\beta}_{5 \mathrm{BI}}+\mathbf{e}$

Where LTDA ( Long term debt to asset ratio) STDA (Short term debt to asset ratio) DE ( Debt equity ratio) TD( Total debt to asset ratio) are capital structure measures as dependent variable while BS (Board size) OC(ownership concentration) IO ( institution ownership) CE ( CEO duality) BI (Board Independence) are corporate governance measures. $\boldsymbol{\beta}_{1} \boldsymbol{\beta}_{2} \boldsymbol{\beta}_{3} \boldsymbol{\beta}_{4} \boldsymbol{\beta}_{5}$ are regression coefficient and $\mathbf{e}$ is the error term.

\section{Insert Table 3 Descriptive analysis}

From table 3 it shows that DE has the highest mean among capital structure variables. The mean for total debt to asset ratio as .52 showing that $52 \%$ of asset of firms on NSE are represented by total debt.

The mean LTDA and STDA are .23 and .33 respectively showing that $23 \%$ and $33 \%$ respectively of assets are represented by long term debt and short term debt respectively for firms listed on the NSE. Thus firms on the NSE opt for short term debt. This could be due to under developed long term debt market in Kenya or the firms lacking collateral and restrictive covenants associated with long term debt.

For corporate governance variables board size has a mean of 7 which shows that most firms has a mean of 7 directors and large block investors hold about $66 \%$ of share capital ,and 59\% of share capital is held by institutions .most firms (93\%) have the CEO doubling up as director.

\section{Inferential an analysis}

\section{insert Table 4. Correlation analysis}

From table 4 correlation analysis total debt to asset ratio as a proxy for capital structure is positively correlated to all corporate governance proxies ( BS \&BI) this is consistent with (Abor2007) and (Rajendran 2012) and( ISR, BI \& ONC) but not significant. and also positively correlated to CEO duality but significant at $95 \%$ confidence level ( $\mathrm{p}$ value< 0.05 ) consistent with (Abor 2007) and (Amarijit2012) this indicates that for firms listed on the NSE when a CEO is also a director it adopts a higher gearing ratio (high debt policy)

Debt equity and short term debt to asset ratio are negatively correlated to board size, institutional share ratio, CEO duality and ownership concentration though not significant. Thus the use of large board, increase in ownership concentration and institutional share ratio for firms registered on NSE tend to avoid use of debts making them less levered.

Insert Table 5 a regression analysis. Insert Table 5 a regression analysis.

\section{Multi-collinearity test}


Multi-collinearitycan be measured using variance inflation factor (VIF) or tolerance test.(In this study VIF was used). from tables $4 \mathrm{a} \& 4 \mathrm{~b}$ regression analysis all VIF values are below 10 which is the critical value rule of thumb when VIF values are less than 10 then there is no multi-collinearity problem (Besley 1980) as sighted in (Jingyu Li 2003)

\section{Durbin Watson test}

Durbin Watson a test used to detect auto correlation from the tables $4 \mathrm{a} \& \mathrm{~b}$ all Durbin Watson values are less than 3 indicating that there is no autocorrelation the rule of thumb.

Adjusted R squared for short term to asset ratio show that $15.6 \%$ of the variance in dependent variables can be explained by independent variables of cooperate governance. WhileAdjusted R squared for total debt to asset ratio is $16.9 \%$.whichshow that $15.6 \%$ of the variance in dependent variables can be explained by independent variables of cooperate governance For long term debt to asset ratio and debt equity to asset ratio is insignificant (very small)

\section{Insert Correlation table 6 with size as a moderating variable}

From table 5 the use size as a moderating variable has had great impact on the relation between capital structure and corporate governance.STDA has now shown to be negatively correlated to CEO duality (-.416) which is significant. This implies when the CEO doubles up as a director as the firm size increase the firm will become less levered and is insignificant.

For TD shows a positive correlation with CEO duality and ONC which is significant at $99 \%$ confidence level, though average .total debt shows positive relationship with all corporate governance proxies for firms listed on the NSE.Debt equity has a negative relationship with CEO duality which is significant at 95\% confidence level. Size as amoderating variable has a great effect on the relationship between capital structure and corporate governance. Results of CEO duality and capital structure (STD and DE) the increase in the size of the firms tend to use pecking order hypothesis where they use internal generated funds and avoid use of debt.

The relationship between ONC ,ISR and TD becomes significant and are positively correlated. Increase the size of the firm large block shareholdings and institutions will allow the firm to be more levered to reduce the impact of tax as debt interest is allowable compared to dividend which is not tax allowable

\section{Insert Regression table 7a with size as a moderating variable \\ Insert Regression table 7bwith size as a moderating variable}

From table 7a \& b with size as a moderating variable VIF values are less than 10 hence no Multi- collinearity problem. Durbin Watson for both tables are less than 3 hence no autocorrelation problem. Adjusted R square for TD and STDA is 0.275 for both meaning $27.5 \%$ of variance in TD/STDA can be explained by independent variables, while $72.5 \%$ by other factors. For DE it shows that $12.1 \%$ of variance in dependent variables can be explained by independent variables. For LTDA R squared shows that $1.8 \%$ of variance in dependent variable can be explained by independent variables.

\section{Conclusion}

Corporate governance has been an important area in research in Kenya. Corporate failures such as Uchumi-super market with a chain of related outlets,Blue Shield insuranceand MugoyaConstruction Company. This alarmed the CMA to strengthen its roles on firms on the NSE to institute corporate governance. In this research the researcher has 5 variables of corporate governance and 4 for capital structure.

Most firms (93\%) on the NSE has the CEO as the director this concentrate decision making authority on an individual leading to high debt policy for firms on NSE. Though most firms on the NSE have a large board size minimum of 7 directors but the proportion of non-executive directors is 1:4 thus they can influence greatly on the decision making, this may compromise corporate governance principles. ONC and ISR holds about $66 \%$ and $59 \%$ of stake on firms on NSE this may influence managerial decisions.

Firms on the NSE tends to prefer STD to LTD. 33\% of asset are represented by STD, LTD market in Kenya is not fully developed and restrictive covenants and lack of collateral pushes firms to use STD. firms on NSE use more debt than equity as $52 \%$ of the asset are represented by total debt this could be due to debt interest is tax allowable while dividend is not. Firms hedge themselves from high tax by using debt.

\section{References}

[1]. The Capital Markets Act Cap. 485a Gazette Notice No. 3362 (2002) Kenya.Capital Markets (Securities ,Public Offers, Listing and Disclosures) Regulations, (2002) .Kenya

[2]. www.kenyacentral.com

[3]. https://www.nse.co.ke/about-nse/history-of-organisation.html

[4]. Abor J. (2007) Corporate governance and financing decisions of Ghanaian listed firms, Emerald Group Publishing Limited, Vol. 7 Iss: 1, pp. $83-92$ 
[5]. Akram B. \& Ahmad A.(2010)The Effect of Corporate Governance and Ownership Structure on Capital Structure of Iranian Listed Companies7th International Conference on Enterprise Systems, Accounting and Logistics, Rhodes Island, Greece

[6]. Noriza M (2010)Corporate Governance Compliance and the Effects to Capital Structure in Malaysia. International journal of economics and finance. vol 2 no 1.

[7]. Rehman, M. A. U., Rehman, R. U., \&Raoof, A. (2010). Does corporate governance lead to a change in the capital struture? American Journal of Social and Management Sciences

[8]. Saad, N.M. (2010).Corporate Governance Compliance and the Effects to Capital Structure in Malaysia International Journal of Economics and Finance, 2(1).

[9]. Rajendran K (2012).Effect Of Corporate Governance On Capital Structure: Case Of The Srilankan Listed Manufacturing Companies. Journal of Arts, Science \& Commerce

[10]. Amarjit G., Nahum B., Harvinder S. \&Charul S. (2012)Corporate Governance and Capital Structure of Small Business Service Firms in India.International Journal of Economics and Finance; Vol. 4, No. 8

[11]. Jingyu L. (2003) dividend clienteles' financial leverage clienteles and determinant of dividends policy under Newzaeland imputation tax regime. A PHD thesis Massey university

\section{Appendices}

Table 1 Percentage of Sample Selected.

\begin{tabular}{|l|l|l|l|}
\hline & Total no of companies & Percentage & Sample \\
\hline Agricultural Sector & 7 & 71 & 5 \\
\hline Automobiles and Accessories & 4 & 75 & 3 \\
\hline Commercial and Services, & 9 & 56 & 5 \\
\hline $\begin{array}{l}\text { Construction and Allied } \\
\text { Sector, }\end{array}$ & 5 & 60 & 3 \\
\hline Energy and Petroleum & 4 & 75 & 3 \\
\hline Insurance & 6 & 33 & 2 \\
\hline Investment & 4 & 50 & 2 \\
\hline Manufacturing and Allied & 9 & 67 & 6 \\
\hline $\begin{array}{l}\text { Telecommunication and } \\
\text { Technology }\end{array}$ & 2 & 50 & 1 \\
\hline TOTAL & 50 & 60 & 30 \\
\hline
\end{tabular}

Table 2 variables used

\begin{tabular}{|l|l|l|}
\hline Variable & Formulae & Symbol \\
\hline $\begin{array}{l}\text { Long Term } \\
\text { Rebt to Asset }\end{array}$ & $\begin{array}{l}\text { Long Term Debt } \\
\text { Total Assets }\end{array}$ & LTDA \\
\hline $\begin{array}{l}\text { Short Term } \\
\text { Debt to Asset } \\
\text { Ratio }\end{array}$ & $\begin{array}{l}\text { Short Term Debt } \\
\text { Total Assets }\end{array}$ & STDA \\
\hline $\begin{array}{l}\text { Debt Equity } \\
\text { ratio }\end{array}$ & Total Debt & DE \\
\hline $\begin{array}{l}\text { Total Debt } \\
\text { Board Size }\end{array}$ & $\begin{array}{l}\text { Long Term Debt }+ \text { Short Term Debt } \\
\text { Total Assets }\end{array}$ & TD \\
\hline $\begin{array}{l}\text { Ownership } \\
\text { Concentration }\end{array}$ & $\begin{array}{l}\text { Stock owned by large investors more than 3\% of total share } \\
\text { capital }\end{array}$ & OC \\
\hline $\begin{array}{l}\text { Institutional } \\
\text { Ownership }\end{array}$ & $\begin{array}{l}\text { Stock owned by institutions } \\
\text { Total number of shares }\end{array}$ & IO \\
\hline CEO duality & If CEO is the chairman 1 if not 0 & CE \\
\hline $\begin{array}{l}\text { Board } \\
\text { Independence }\end{array}$ & $\begin{array}{l}\text { Number of non- executive directors } \\
\text { Total number of directors }\end{array}$ & BI \\
\hline
\end{tabular}

Table 3 Descriptive analysis

\begin{tabular}{|l|l|l|l|l|l|l|}
\hline Variable & Minimum & maximum & mean & Std deviation & skewness & Kurtosis \\
\hline DE & 00 & 101.5 & 9.64 & 18.08 & 3.44 & 13.25 \\
\hline TD & .01 & 3.87 & .52 & .38 & 1.67 & 7.77 \\
\hline LTDA & 00 & 2.64 & .23 & .22 & 1.23 & 4.10 \\
\hline STDA & 00 & 2.76 & .33 & .28 & 1.49 & 5.05 \\
\hline ONC & .20 & .94 & .66 & .16 & -.92 & 1.66 \\
\hline BI & 00 & .83 & .25 & .29 & .66 & -1.63 \\
\hline BS & $\mathbf{5 . 0}$ & 21.0 & 7.27 & 3.48 & 2.43 & 7.48 \\
\hline ISR & .03 & .91 & .59 & .19 & -.86 & 1.05 \\
\hline CED & 00 & 1.0 & .93 & .25 & -3.66 & 12.21 \\
\hline
\end{tabular}


Table 4. Correlation analysis

\begin{tabular}{|c|c|c|c|c|c|c|c|c|}
\hline & BS & ISR & CED & ONC & STDA & LTDA & TD & $\mathrm{DE}$ \\
\hline BS & 1 & & & & & & & \\
\hline ISR & $\begin{array}{l}-.086 \\
(.651)\end{array}$ & 1 & & & & & & \\
\hline CED & $\begin{array}{r}.195 \\
(.313)\end{array}$ & $\begin{array}{r}.022 \\
(.909)\end{array}$ & 1 & & & & & \\
\hline $\mathrm{BI}$ & $\begin{array}{l}.651^{* *} \\
(.00)\end{array}$ & $\begin{array}{l}-.04 \\
(.832)\end{array}$ & $\begin{array}{l}.192 \\
(.308)\end{array}$ & 1 & & & & \\
\hline ONC & $\begin{array}{l}.441^{x} \\
(.014)\end{array}$ & $\begin{array}{l}657^{* *} \\
(.00)\end{array}$ & $\begin{array}{r}-.259- \\
(.167)\end{array}$ & $\begin{array}{l}-.0441 \\
(819)\end{array}$ & & & & \\
\hline STDA & $\begin{array}{l}-.013 \\
(.945)\end{array}$ & $\begin{array}{l}-.064 \\
(.737)\end{array}$ & $\begin{array}{l}-.277 \\
(.138)\end{array}$ & $\begin{array}{l}.061 \\
(.748)\end{array}$ & $\begin{array}{l}-.173 \\
(.361)\end{array}$ & 1 & & \\
\hline LTDA & $\begin{array}{l}.282 \\
(.132)\end{array}$ & $\begin{array}{c}-.032 \\
(.876)\end{array}$ & $\begin{array}{l}-.118 \\
(.534)\end{array}$ & $\begin{array}{l}-.205 \\
(276)\end{array}$ & $\begin{array}{l}.057 \\
(.764)\end{array}$ & $\begin{array}{l}-.270 \\
(.149)\end{array}$ & 1 & \\
\hline TD & $\begin{array}{l}.097 \\
(.612)\end{array}$ & $\begin{array}{l}.142 \\
(.454)\end{array}$ & $\begin{array}{l}.477^{* *} \\
(.008)\end{array}$ & $\begin{array}{l}.081 \\
8) \quad(.670)\end{array}$ & $\begin{array}{l}.083 \\
(.662)\end{array}$ & $\begin{array}{l}-540^{* *} \\
(.002)\end{array}$ & $\begin{array}{l}-.322 \\
(.083)\end{array}$ & 1 \\
\hline $\mathrm{DE}$ & $\begin{array}{l}-.327 \\
(.077)\end{array}$ & $\begin{array}{c}-.042 \\
(.826)\end{array}$ & $\begin{array}{l}-.113 \\
(.553)\end{array}$ & $\begin{array}{l}-.166 \\
(.382)\end{array}$ & $\begin{array}{l}.015 \\
(.937)\end{array}$ & $\begin{array}{l}.072 .654^{* *} \\
(.705)\end{array}$ & $\begin{array}{c}-.150 \\
(.000)\end{array}$ & $\begin{array}{l}1 \\
\quad(.429)\end{array}$ \\
\hline
\end{tabular}

Table 5 a regression analysis.

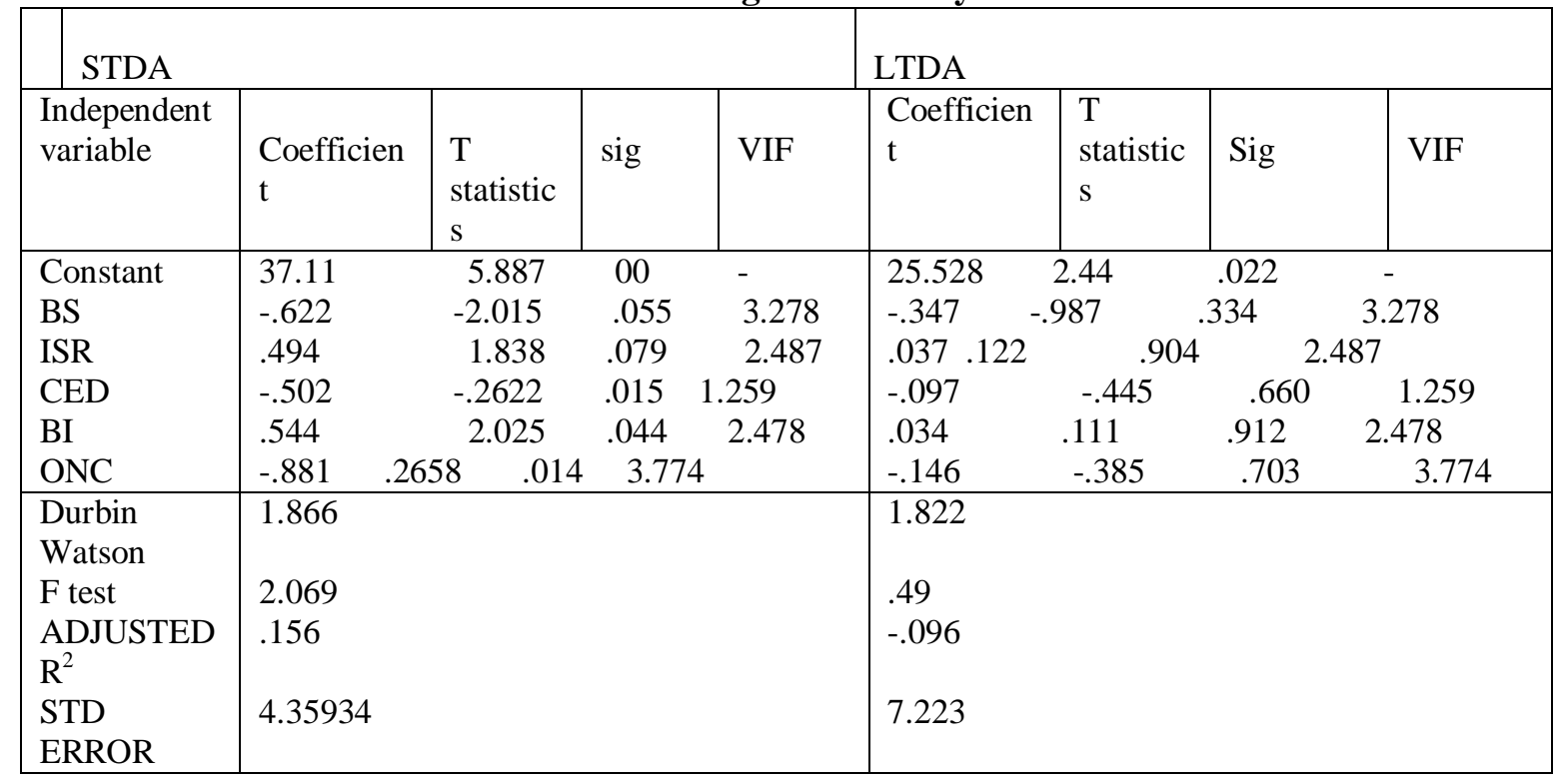

Table $5 \mathrm{~b}$ regression analysis.

\begin{tabular}{|l|l|l|l|l|l|l|l|l|}
\hline & \multicolumn{3}{|c|}{ TD } & \multicolumn{3}{c|}{ DE } \\
\hline $\begin{array}{l}\text { Independent } \\
\text { variable }\end{array}$ & Coefficient & $\begin{array}{l}\text { T } \\
\text { statistics }\end{array}$ & Sig & VIF & coefficient & $\begin{array}{l}\text { T } \\
\text { statistics }\end{array}$ & Sig & VIF \\
\hline Constant & -2.293 & -.315 & .755 & - & 32.370 & 5.16 & 00 & - \\
BS & .353 & 1.152 & .261 & 3.270 & -.667 & -1.988 & .058 & 3.270 \\
ISR & -.179 & -.672 & .548 & 2.487 & .212 & .725 & .475 & 2.487 \\
CED & .591 & -3.113 & .005 & 1.259 & -.163 & -.780 & .443 & 1.259 \\
\hline
\end{tabular}


Capital Structure andCorporate Governance practices. Evidence from Listed Non-Financial Firms on

\begin{tabular}{|l|llll|llll|}
\hline BI & -.248 & -.929 & .362 & 2.478 & .289 & .989 & .332 & 2.478 \\
ONC & .50 & 1.522 & .141 & 3.774 & -.451 & -1.251 & .223 & 3.774 \\
& & & & & & & & \\
\hline Durbin & 1.474 & & & & 1.135 & & & \\
Watson & & & & & 1.005 & & & \\
F test & 2.18 & & & & .001 & & & \\
ADJUSTED & .169 & & & & & & & \\
$\mathrm{R}^{2}$ & & & & & 4.3385 & & & \\
STD ERROR & 5.0351 & & & & & & & \\
\hline
\end{tabular}

Correlation table 6 with size as a moderating variable

\begin{tabular}{|c|c|c|c|c|c|c|c|c|}
\hline & BSsz & IRSsz & CEDsz BIsz & ONCsz & STD & LTD & TD & $\mathrm{DE}$ \\
\hline BSsz & 1 & & & & & & & \\
\hline IRSsz & $\begin{array}{l}.442^{*} \\
(.014)\end{array}$ & 1 & & & & & & \\
\hline CEDsz & $\begin{array}{l}.683^{* *} \\
(00)\end{array}$ & $\begin{array}{c}.642 * * \\
(00)\end{array}$ & 1 & & & & & \\
\hline BIsz & $\begin{array}{l}.786^{* *} \\
(00)\end{array}$ & $\begin{array}{c}.398 * * \\
(.029)\end{array}$ & $\begin{array}{l}516^{* * *} \\
(.003)\end{array}$ & 1 & & & & \\
\hline ONCsz & $\begin{array}{l}.295 \\
(.113)\end{array}$ & $\begin{array}{l}.850 * * \\
(00)\end{array}$ & $\begin{array}{l}.614^{* *} \\
(00)\end{array}$ & $\begin{array}{l}.384 * * \\
(.036)\end{array}$ & 1 & & & \\
\hline STDA & $\begin{array}{l}-.115 \\
(.544)\end{array}$ & $\begin{array}{l}-.365 \\
(.047)\end{array}$ & $\begin{array}{r}-.416^{*} \\
(.022)\end{array}$ & $\begin{array}{l}.032 \\
(.969)\end{array}$ & $\begin{array}{l}-.504 \\
(003)\end{array}$ & 1 & & \\
\hline LTDA & $\begin{array}{l}-.341 \\
(.065)\end{array}$ & $\begin{array}{l}-.208 \\
(.269)\end{array}$ & $\begin{array}{l}-.308 \\
(.098)\end{array}$ & $\begin{array}{l}-.345 \\
(.062)\end{array}$ & $\begin{array}{r}-.245 \\
(.192)\end{array}$ & $\begin{array}{l}-.270 \\
(.149)\end{array}$ & 1 & \\
\hline TD & $\begin{array}{l}.212 \\
(.260)\end{array}$ & $\begin{array}{c}.444^{*} \\
(.014)\end{array}$ & $\begin{array}{l}.557 * * \\
(.001)\end{array}$ & $\begin{array}{l}.209 \\
(.268)\end{array}$ & $\begin{array}{c}.540 * * \\
(.002)\end{array}$ & $\begin{array}{c}-.540 * * \\
(.002)\end{array}$ & $\begin{array}{l}-.322 \\
(.083)\end{array}$ & 1 \\
\hline DE & $\begin{array}{l}-.436 \\
(.116)\end{array}$ & $\begin{array}{l}-.284 \\
(.128)\end{array}$ & $\begin{array}{l}-384 * \\
(.036)\end{array}$ & $\begin{array}{l}.368 \\
(.046)\end{array}$ & $\begin{array}{c}-345 \\
(.063)\end{array}$ & $\begin{array}{l}.072 \\
(.705)\end{array}$ & $\begin{array}{l}.654 * * \\
(00)\end{array}$ & $\begin{array}{ll}-150 & 1 \\
(.429)\end{array}$ \\
\hline
\end{tabular}

*correlation is significant at the 0.01 level (2-tailed)

*correlation is significant at the 0.05 level (2-tailed

Regression table 7a with size as a moderating variable

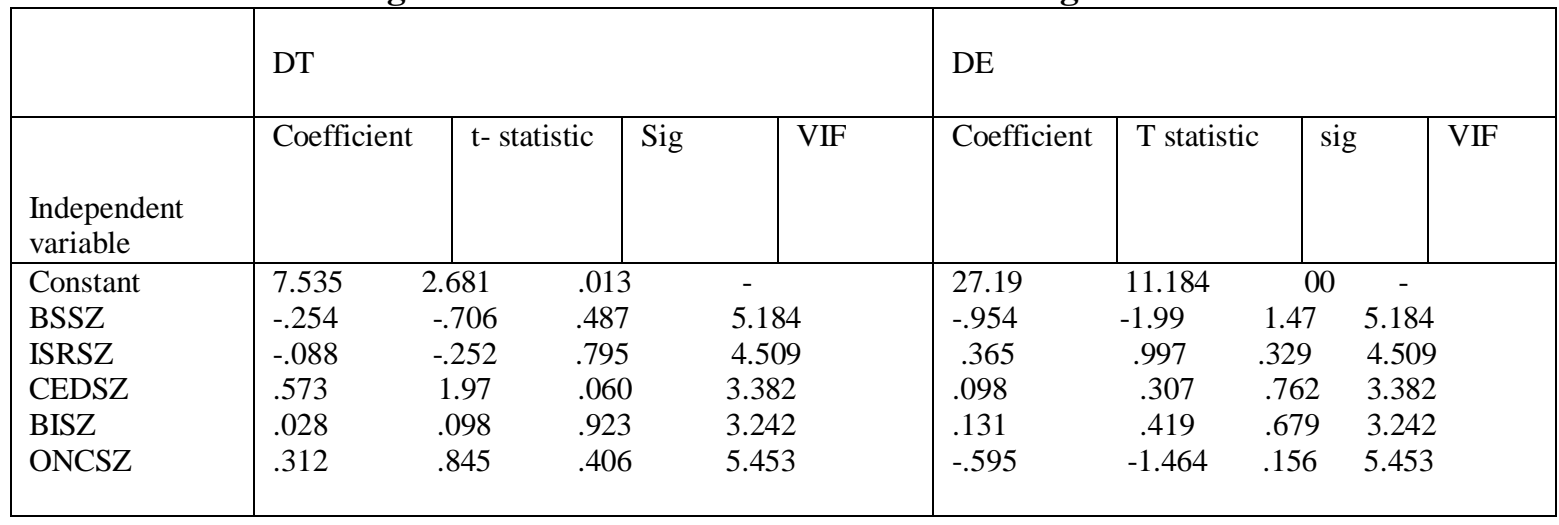




\begin{tabular}{|l|l|l|}
\hline Durbin Watson & 1.716 & 1.113 \\
F test & & 1.802 \\
Adjusted R & 3.204 & .121 \\
square & .275 & 4.0682 \\
Std error & 4.70211 & \\
\hline
\end{tabular}

\section{Regression table $7 \mathrm{~b}$ with size as the moderating variable}

\begin{tabular}{|c|c|c|c|c|c|c|c|c|}
\hline \multirow[b]{2}{*}{$\begin{array}{l}\text { Independent } \\
\text { variable }\end{array}$} & \multicolumn{4}{|l|}{ STDA } & \multicolumn{4}{|l|}{ LTDA } \\
\hline & $\begin{array}{l}\text { Coefficien } \\
\mathrm{t}\end{array}$ & $\begin{array}{l}\mathrm{t}- \\
\text { statistic }\end{array}$ & Sig & VIF & $\begin{array}{l}\text { Coefficie } \\
\text { nt }\end{array}$ & t statistic & sig & VIF \\
\hline Constant & 26.625 & 10.855 & 00 & - & 22.531 & 5.416 & 00 & - \\
\hline BSSZ & -.252 & -.688 & .498 & 5.184 & -.219 & -.514 & .612 & 5.184 \\
\hline ISRSZ & .413 & 1.211 & .238 & 4.509 & .200 & .504 & .619 & 4.509 \\
\hline CEDSZ & -192 & -.6511 & .521 & 3.382 & -.049 & -.142 & .888 & 3.382 \\
\hline BISZ & .423 & 1.62 & .157 & 3.242 & -.364 & -.123 & .719 & 3.242 \\
\hline ONCSZ & -.837 & -2.231 & .035 & 5.453 & -.622 & -.272 & .540 & 5.453 \\
\hline $\begin{array}{l}\text { Durbin } \\
\text { Watson }\end{array}$ & 1.716 & & & & 1.946 & & & \\
\hline F test & 3.204 & & & & .896 & & & \\
\hline $\begin{array}{l}\text { Adjusted R } \\
\text { square }\end{array}$ & .275 & & & & .018 & & & \\
\hline Std error & 4.70211 & & & & 6.961 & & & \\
\hline
\end{tabular}

